СД-5.

\title{
ГИДРОХИМИЧЕСКИЕ ИССЛЕДОВАНИЯ ПОВЕРХНОСТНЫХ ВОД МЕТОДОМ КАПИЛЛЯРНОГО ЭЛЕКТРОФОРЕЗА ПРИ ПОИСКЕ, РАЗВЕДКЕ И РАЗРАБОТКЕ МЕСТОРОЖДЕНИЙ НЕФТИ И ГАЗА НА ПРИМЕРЕ РЕКИ УЛАХАН-ВАВА
}

\author{
Бушеева Г.А., Маркова Ю.Л. \\ $\mathrm{AO}$ «Сибирский научно-исследовательский институт геологии, \\ геофизики и минерального сырья», Новосибирск, Россия \\ galyabush@mail.ru
}

DOI: 10.26902/ASFE-11_98

В рамках данной работы рассматривается применение капиллярного электрофореза для анализа природных объектов с целью выявления крупных нефтегазопоисковых объектов в Восточной Сибири (исследования входят в комплекс геологических, геофизических и гидрогазогеохимических работ, проводимых на западных склонах Непско-Ботуобинской антеклизы, Присаяно-Енисейской синеклизы, Сюгджерской седловины и прилегающих территорий).

Объект исследования - природная вода, отобранная из реки Улахан-Вава в летний период. Проектом предусматривалась гидрогазогеохимическая съемка по двум опорным маршрутам газогидрогеохимического опробования, которые проходили по р. Вилюй с пересечением Западно-Якутского барьерно-рифового комплекса, неизученной зоны сочленения восточного борта Курейской синеклизы и Непско-Ботуобинской антеклизы, с выходом в Нижнечонский нефтегазоперспективный район.

Улахан-Вава - река в Азиатской части России, в Восточной Сибири, в Республике Саха (Якутия); правый приток реки Вилюй (бассейн Лены). Улахан-Вава берёт начало в центральной части Вилюйского плато на Среднесибирском плоскогорье. Длина реки 374 км, площадь бассейна 12,5 тыс. км². Пробоотбор проводился по маршруту, ведущему вниз по течению Улахан-Вавы, а так же в месте впадения её в реку Вилюй.

Для исследования химического состава природных вод в Испытательной лаборатории $\mathrm{AO}$ «СНИИГГиМС» применяется метод капиллярного электрофореза. Объекты анализа представляют собой многокомпонентные растворы сложного состава. Метод капиллярного электрофореза позволяет анализировать ионные и нейтральные компоненты различной природы. Основными преимуществами данного метода являются: высокая эффективность разделения компонентов смесей; быстрота проведения анализа; крайне низкий расход реактивов; минимальный объём анализируемого образца; простая пробоподготовка; невысокая стоимость оборудования; возможность определения большого количества элементов за один анализ.

Анализ поверхностных вод проводился с помощью системы капиллярного электрофореза серии «Капель - 105 М», согласно МВИ М 01-45-2009. В результате исследований было обнаружено повышенное содержания бромид-иона и хлорид-иона в образцах, отобранных на определённых участках маршрута опробования. Принимая во внимание материалы геологической съёмки и результаты химических анализов, можно прогнозировать в районе пробоотбора зону восходящей разгрузки глубинных флюидов, связанную с системами глубинных разломов и вулканическими аппаратами (трубки взрыва) в поле развития туфо-трапповых толщ. Здесь наблюдаются очаги и линейные проявления гидрогеохимических аномалий в виде поверхностных источников слабосоленых вод с высоким содержанием хлорид-иона. 